\title{
Sustaining a Cleaner Environment by Curbing Down Biomass Energy Consumption
}

\author{
Abubakar Hamid Danlami and Shri Dewi Applanaidu
}

\section{Contents}

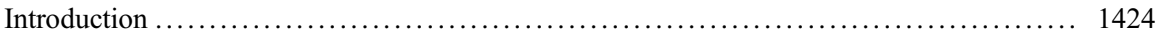

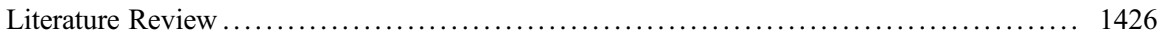

Theoretical Frameworks ............................................... 1427

Equilibrium Level of Utility for Households That Use Only One of These Energy

Sources .......................................................... 1428

Equilibrium Point for Households That Use Gas as Their Only Source of Energy ...... 1428

Derivation of Equilibrium Point for Households That Use Liquid Fuel as the Only

Source of Energy ..................................................... 1429

Utility Maximization Point for Households That Use Only Biomass Energy ............ 1429

Utility Maximization of Households That Use All the Four Source of Energy

Together ............................................................. 1430

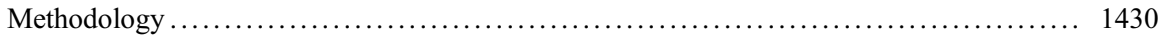

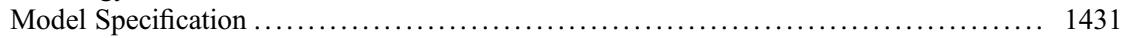

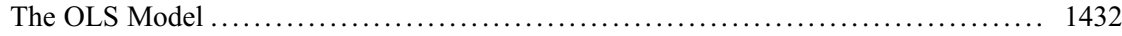

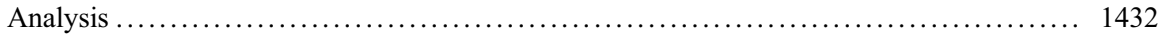

Determinants of Household Energy Switching .............................. 1433

Determinants of Household Traditional Energy Use ........................... 1435

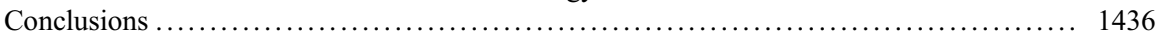

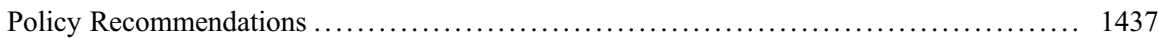

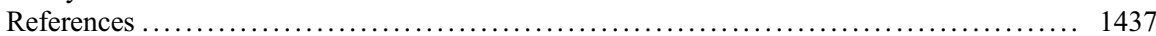

This chapter was previously published non-open access with exclusive rights reserved by the Publisher. It has been changed retrospectively to open access under a CC BY 4.0 license and the copyright holder is "The Author(s)". For further details, please see the license information at the end of the chapter.
A. H. Danlami $(\bowtie)$
Department of Economics, Faculty of Social Sciences, Bayero University Kano, Kano, Nigeria
S. D. Applanaidu
Department of Economics and Agribusiness, School of Economics, Finance and Banking, College of Business, Universiti Utara Malaysia, Sintok, Malaysia
e-mail: dewi@uum.edu.my




\section{Abstract}

Environmental degradation, soil erosion, and desertification are some of the consequences of high rate of traditional biomass fuel use by households in developing countries. The critical issues to raise here are how can these households be encouraged to change their energy consumption behavior? What are the factors that cause the rampant use of biomass fuel in developing countries? How and to what extent can these factors be manipulated so that households in developing countries are encouraged to adopt clean energy fuel an alternative to the most widely used biomass fuel? Therefore, this chapter tries to find answer to the above questions raised, by carrying out an in depth analysis of households' use of biomass fuel in developing countries using Bauchi State, Nigeria, as the case study. Cluster area sampling technique was utilized to generate the various responses, where a total number of 539 respondents were analyzed. The study estimated ordered logit model to analyze the factors that influence the movement of households along the energy ladder from nonclean energy to the cleaner energy. Furthermore, Ordinary Least Squares (OLS) model was estimated to analyze the impacts of socio-economic, residential, and environmental factors on biomass energy consumption. It was found that age of the household head and his level of education, income, living in urban areas, home ownership, and hours of electricity supply have positive and significant impact on household energy switching from traditional biomass energy use to the cleaner energy. Therefore, policies that will enhance household income and the increase in the availability of cheap cleaner energy will encourage households switching to cleaner energy sources thereby reducing the level of environmental pollution in the study area.

\section{Keywords}

Clean-energy $\cdot$ Households $\cdot$ OLS, Ordered-logit $\cdot$ Traditional-biomass

\section{Introduction}

Climate change which is the variation in climate overtime and its impacts on the environment and socio-economic systems now constitute the most important environmental problem facing mankind. According to UNDP (2013), climate change can affect both the human and the entire natural systems which pose a threat to human development and survival. Among the most important factors that caused climate change and environmental pollution is the wide spread use of biomass energy. Biomass fuels, which constitute animal dung, crop residues, fuel-wood, and charcoal, are among some of the most widely used fuels for cooking and heating, particularly in developing countries (Yamamoto et al. 2009). Currently, more than two billion people rely on biomass fuel globally to satisfy their basic energy needs. That is why this type of fuel accounts for about $20 \%$ of energy supply for the whole 
world. IEA (2011) argued that if proper measures were not taken, the number of biomass fuel users globally may increase to about 2.7 billion people by the year 2030. A large number of biomass energy users, especially in traditional ways, are found mostly in Asia and Africa. For instance, the IEA (2011) reported that biomass fuel accounts for more than $50 \%$ of Africa's energy utilization. In Nigeria, the wide use of biomass fuel at household level is more than $70 \%$. Coming down to the state level, the rate of biomass fuel use by households is about more than $90 \%$ in Bauchi State, Nigeria (NBS 2012).

However, such wider use of biomass fuel is unwholesome for human living and their environment. For instance, when combining $\mathrm{CO}_{2}$ emissions and other GHG in a single index, biomass fuel scores much higher than other fossil fuels like LPG and kerosene. Moreover, there is higher correlation between the use of biomass fuel and indoor air pollution (Desalu et al. 2012; Risseeuw 2012). Such indoor air pollution causes about 1.5 to 2 million losses of lives worldwide yearly. Environmental degradation, soil erosion, and desertification are some of the consequences of high rate of biomass fuel use in developing countries. In fact, Nigeria has been facing an annual average rate of deforestation over a previous decade due to high rate of biomass fuel use. Available data has shown that the nation's 15 million hectares of forest and woodland reserves could be depleted within the next 50 (Nnaji et al. 2012). In Bauchi State, the rampant use of biomass energy is so great to the extent of more than $600 \mathrm{~kg}$ per household monthly (Danlami et al. 2017). This has posed negative impacts on the inhabitant of the State such as the systematic destruction of the State's forest reserves and woodlands, soil erosion, and desertification whereby the State losses not less than $1 \mathrm{~km}$ of land yearly due to desertification as a result of high rate of felling trees (Danlami et al. 2017).

That is why the defunct United Nations Millennium Project recommended halving the number of households that depend on traditional biomass fuel by the year 2015, the target that was not complied by most of the participating countries including Nigeria (Naibbi and Healey 2013). The critical issues to raise here are that how can these households be encouraged to change their energy consumption behavior? what are the factors that cause the rampant use of biomass fuel in developing countries? how and to what extent can these factors be manipulated so that households in developing countries are encouraged to adopt clean energy fuel an alternative to the most widely used traditional biomass fuel? This is because clean fuel has greater capacity to do useful work. The use of clean fuel is an imperative to improve the standard of living of the households that heavily rely on biomass fuel (Lee 2013). Therefore, in line with the above issues raised, this chapter tries to find answer to the above questions raised by carrying out an in depth analysis of households' use of biomass fuel in developing countries using Bauchi State, Nigeria, as the case study. The remaining part of the chapter consists sections as follows. Section "Literature Review" constitutes review of related literature. Section "Theoretical Frameworks" is theoretical and conceptual frameworks of the study. Section "Methodology" highlights the methodology adopted. Section "Analysis" the discussion of findings. Section "Conclusions" highlights chapter conclusion. The last section constitutes the policy implications and recommendations. 


\section{Literature Review}

Studies that analyzed energy utilization can be classified into two categories. The first group consists of those studies (Danlami et al. 2018a, 2019a) that analyze aggregate energy consumption using time series data. Most of these studies concluded that energy consumption is highly correlated with environmental degradation. However, these conclusions have limited practical applicability at a microlevel, because the energy consumption behavior of households is heterogeneous, which is usually ignored in studies that utilized time series data. Moreover, the second category of studies are those that analyzed household energy consumption using microdata approach (Lee 2013; Mensah and Adu 2013; Ozcan et al. 2013; Abdurrazak et al. 2012; Couture et al. 2012; Laureti and Secondi 2012; Onoja 2012; Oyekale et al. 2012; Song et al. 2012; Ganchimeg and Havrland 2011; Jingchao and Kotani 2011; Jumbe and Angelsen 2010; Osiolo 2010; Suliman 2010; Danlami and Islam 2020; Danlami et al. 2017; Nlom and Karimov 2014; Ogwumike et al. 2014). These studies arrived at different conclusions based on the socio-economic, demographic, home, and environmental characteristics of the households under consideration.

The composition and type of socio-demographic factors of households determine their fuel switching and consumption behavior. For instance, Laureti and Secondi (2012) indicated that households which comprise of couples with children tend to adopt less of oil and electricity and more of coal-wood when compared with a household of a single person. This is contrary to the findings by Danlami et al. (2017) which concluded that the household that is headed by a married individual has higher odd of adopting clean fuel than otherwise. Whereas some previous studies (Osiolo 2010; Jumbe and Angelsen 2010; Nlom and Karimov 2014) reported no significant relationship between the gender of the household head and its energy consumption behavior, a study by Mensah and Adu (2013) found that there is a significant negative relationship between the household head being male and the adoption of clean energy. Meanwhile, age of the household head was found to have a negative impact on the adoption of clean energy (Suliman 2010; Mensah and Adu 2013; Nlom and Karimov 2014). Households adopt less clean energy source when the head is older. Additionally, the household head level of education was found to exact a positive impact on the adoption of clean energy. The higher the level of education of the household head, the lower the probability of adopting nonclean energy (Eakins 2013; Mensah and Adu 2013; Ozcan et al. 2013). The number of a household's members (i.e., household size) affects the household's energy switching decision, the larger the size of a household, the lesser the adoption of clean energy. This assertion is supported by previous studies (Ozcan et al. 2013; Mensah and Adu 2013; Suliman 2010; Heltberg 2005).

The factors that measure the economic status of the household influence the households' fuel consumption decision. For instance, studies have established that there is a positive relationship between income and adoption of clean energy (Danlami et al. 2017; Mensah and Adu 2013; Ozcan et al. 2013; Couture et al. 2012). Poorer households especially in developing countries tend to adopt biomass 
fuels like firewood, plant residues, and animal dung. Furthermore, number of energy consuming appliances increases the quantity of energy consumption by households (Danlami 2017a; Eakins 2013). The higher the number of energy consuming appliances at home, the lesser the odd of adopting biomass source of energy (Danlami 2017b). Moreover, energy price has a negative relationship with energy consumption. When the price of a particular energy source is high, households switch to other alternative fuel available. This is in line with law of demand and also has been established by previous studies (Danlami 2017a; Nlom and Karimov 2014; Lee 2013).

Furthermore, the characteristics of the building in which the households live also affect their energy choice behavior. Factors such as size of the building, number of rooms in the home, share of dwelling and dwelling ownership have been established by previous studies to influence the manner of household energy consumption behavior (Danlami et al. 2017; Eakins 2013; Mensah and Adu 2013; Tchereni 2013). Lastly, environmental factors such as location of home, the extent of electricity supply, the main source of cooking, and lighting fuel in the area were found to influence the manner of household energy consumption. Households that live in the rural areas or the area whereby there is a wide spread use of biomass fuel tend to adopt biomass fuel as their main source of energy (Danlami 2017a, b; Ozcan et al. 2013).

Based on the above-reviewed literature, it can be seen that there exist inconsistences as per the findings and conclusions of previous studies on the factors influencing household energy consumption and switching behavior, from one place to another, due to differences in environmental factors, cultural factors, socio-economic settings, as well as differences in the average level of development among different regions. Therefore, additional study on household energy choice and consumption in a specific area is an addition to the existing literature as argued by the previous studies (Danlami et al. 2015, 2017).

\section{Theoretical Frameworks}

Households mostly use energy for indirect satisfaction mainly to produce another commodities or services (modified from Danlami et al. 2016). Households utilized energy from different sources for the purpose of maximizing satisfaction. This optimal level satisfaction is usually attained at the equilibrium point of particular energy consumption. For instance, equation (1) indicates a given utility function of energy consumption:

$$
U=f\left(\in_{c} \mathrm{G}_{s} \mathscr{L}_{f} \mathcal{B}_{b}\right)
$$

Subject to household budget constraint as in equation (2):

$$
Y=\mathrm{P}_{c} \epsilon_{c}+\mathrm{P}_{s} \mathrm{G}_{s}+\mathrm{P}_{f} \mathcal{L}_{f}+\mathrm{P}_{b} \mathcal{B}_{b}
$$


where $U=$ utility, $\in_{c}=$ electric energy, $\mathrm{G}_{s}=$ gas energy, $\mathcal{L}_{f}=$ liquid energy (i.e., fuel), $\mathcal{B}_{b}=$ biomass energy, $Y=$ income of household and $\mathrm{P}=$ price of the relevant energy.

To find the maximum point of household energy utilization, we form Langarangian multiplier function as in equation (3):

$$
L=f\left(\in_{c} \mathrm{G}_{s} \mathcal{L}_{f} \mathcal{B}_{f}\right)+\lambda\left(Y-\mathrm{P}_{c} \epsilon_{c}+\mathrm{P}_{s} \mathrm{G}_{s}+\mathrm{P}_{f} \mathcal{L}_{f}+\mathrm{P}_{b} \mathcal{B}_{b}=0\right)
$$

Using equation (3), we can analyze the maximum point of utility for:

(i) Household that use only one of these energy sources

(ii) Households that use all of these energy sources

\section{Equilibrium Level of Utility for Households That Use Only One of These Energy Sources}

Assuming the households use only electricity as its sole source of energy, the utility maximization point will be

$$
\begin{gathered}
\frac{\partial L}{\partial \epsilon_{c}}=f_{c}^{\prime}-\lambda P_{c}=0 \\
f_{c}^{\prime}=\lambda P_{c}
\end{gathered}
$$

Since the household utilized only single source of energy, $\lambda=1$

$$
f_{c}^{\prime}=P_{c}
$$

Equation (6) indicates the point of utility maximization from using electric source of energy where the marginal utility obtained from consuming extra unit of electricity is equal to the price of that additional unit of electricity. Any increase in the consumption of electricity above the equilibrium level implies decrease in the total utility, while consumption of electricity below the equilibrium level implies that the total utility of electricity is not maximized because additional unit of electricity consumed will lead to increase in the total utility, until the above equilibrium point is reached.

\section{Equilibrium Point for Households That Use Gas as Their Only Source of Energy}

In this case, we conduct the partial derivation of equation (3) with respect to gas. This is indicated in equation (7): 


$$
\begin{gathered}
\frac{\partial L}{\partial \mathrm{G}_{s}}=f_{s}^{\prime}-\lambda P_{s}=0 \\
f_{s}^{\prime}=\lambda P_{s}
\end{gathered}
$$

By definition, $\lambda=1$, therefore, the utility maximization point will be

$$
f_{s}^{\prime}=P_{s}
$$

that is, the point where the additional satisfaction obtained from using extra amount of gas is equal to the price of that additional unit of gas.

\section{Derivation of Equilibrium Point for Households That Use Liquid Fuel as the Only Source of Energy}

Here, we find the partial derivative of equation (3) with respect to the liquid fuel as in equation (10):

$$
\begin{gathered}
\frac{\partial L}{\partial \mathcal{L}_{f}}=f_{f}^{\prime}-\lambda P_{f}=0 \\
f_{f}^{\prime}=\lambda P_{f}
\end{gathered}
$$

Since $\lambda=1$ (for households that use only one source of energy)

$$
f_{f}^{\prime}=P_{f}
$$

\section{Utility Maximization Point for Households That Use Only Biomass Energy}

The partial derivative of equation (3) with respect to biomass energy is given by:

$$
\begin{gathered}
\frac{\partial L}{\partial \mathcal{B}_{b}}=f_{b}^{\prime}-\lambda P_{b}=0 \\
f_{b}^{\prime}=\lambda P_{b}
\end{gathered}
$$

Since $\lambda=1$

$$
f_{b}^{\prime}=P_{b}
$$

Equation (15) indicates the utility maximization point for household that utilizes only biomass energy. This is the point where the additional satisfaction obtained 
from using an additional bundle of biomass energy is equal to the price of that additional bundle.

\section{Utility Maximization of Households That Use All the Four Source of Energy Together}

In this situation, the utility of using energy is maximized, by consuming the energy up to the level where the ratio of extra satisfaction from using the additional amount of energy to their prices is equal. Taking back the earlier Langarangian multiplier utility function and the constraints for energy use

$$
L=f\left(\in_{c} \mathrm{G}_{s} \mathcal{L}_{f} \mathcal{B}_{b}\right)+\lambda\left(Y-\mathrm{P}_{c} \in_{c}+\mathrm{P}_{s} \mathrm{G}_{s}+\mathrm{P}_{f} \mathcal{L}_{f}+\mathrm{P}_{b} \mathcal{B}_{b}=0\right)
$$

The partial derivatives with respect to each of the energy source are:

$$
\begin{gathered}
\frac{\partial L}{\partial \epsilon_{c}}=f_{c}^{\prime}-\lambda P_{c}=0 \\
\frac{\partial L}{\partial \mathrm{G}_{s}}=f_{s}^{\prime}-\lambda P_{s}=0 \\
\frac{\partial L}{\partial \mathcal{L}_{f}}=f_{f}^{\prime}-\lambda P_{f}=0 \\
\frac{\partial L}{\partial \mathcal{B}_{b}}=f_{b}^{\prime}-\lambda P_{b}=0 \\
\lambda=\frac{f_{c}^{\prime}}{P_{c}}=\frac{f_{s}^{\prime}}{P_{s}}=\frac{f_{f}^{\prime}}{P_{f}}=\frac{f_{b}^{\prime}}{P_{b}}
\end{gathered}
$$

That is the utility maximization point for households that use all the four source of energy is for them to consume at the point where the ratio of the extra satisfaction from using additional unit from each of the energy source to their prices are equal.

\section{Methodology}

Following Danlami et al. (2019b), the total sample size was determined based on Dillman (2011). A total of 750 questionnaires were distributed based on cluster area sampling method. Finally about 548 filled questionnaires were returned back (which is more than $70 \%$ of the total number of the issued questionnaires) out of which 9 
questionnaires were discarded. Multistage cluster sampling was utilized as the sampling technique.

\section{Model Specification}

\section{Ordered Logit Models}

In order to satisfy the first objective of this chapter which is to assess the determinants of household fuel switching up the ladder from traditional biomass energy to the cleaner source of energy, ordered logit model was employed. Since household fuel switching consists of movement up the energy ladder in a hierarchical order which is the basis for ordered models (Kofarmata 2016). Therefore, due to the ordinal nature of the dependent variable, it is stated as movement in fuel the household switching from traditional biomass energy, transitional energy (kerosene), and the cleaner energy (gas and electricity sources of energy). Thus, the model can be stated as in equation (22):

$$
y_{i}=\beta X_{i}+\varepsilon_{i}
$$

where $y_{i}$ is the observed and exact dependent variable (categories of fuel switching in hierarchical order); coded as $0,1, \ldots . . n, X_{i}$ is the vector of the independent variables. $\beta$ is the vector of parameters to be estimated and $\varepsilon_{i}$ is the random variable for the ordered logit model.

If the score on the observed variable say $y_{i}$ is 0 , means that the household uses traditional biomass energy. However, if the household adopts the transitional fuel (such as kerosene), then $\mathrm{y}_{\mathrm{i}}=1$; and if the household adopts cleaner source of energy (electricity/gas) then $y_{i}=2$. Then the estimated empirical model is written as:

$$
\begin{aligned}
Y_{i}= & \alpha_{0}+\beta_{1} \mathrm{GEN}_{i}+\beta_{2} \mathrm{AGE}_{i}+\beta_{3} \mathrm{EDU}_{i}+\beta_{4} \mathrm{HHS}_{i}+\beta_{5} \mathrm{INC}_{i}+\beta_{6} \mathrm{LOC}_{i} \\
& +\beta_{7} \mathrm{NRM}_{i}+\beta_{8} \mathrm{DSH}_{i}+\beta_{9} \mathrm{HRSE}_{i}+\beta_{10} \mathrm{PFW}_{i}+\beta_{11} \mathrm{NCF}_{i} \\
& +\beta_{12} \mathrm{HAPP}_{i}+\beta_{13} \mathrm{HOWN}_{i}+\varepsilon_{i}
\end{aligned}
$$

$Y_{i}=$ The dependent ordered variables summarized as: Traditional biomass $\left(y_{i}=0\right)$,

Transitional energy $\left(y_{i}=1\right)$ and Cleaner energy $\left(y_{i}=2\right)$

$\mathrm{GEN}_{i}=$ Gender of the head of household

$\mathrm{AGE}_{i}=$ Age of the head of household

$\mathrm{EDU}_{i}=$ Level of education of the head of household

$\mathrm{HHS}_{i}=$ Size of the household

$\mathrm{INC}_{i}=$ Monthly income of the head of household

$\mathrm{LOC}_{i}=$ Home location of the household

$\mathrm{NRM}_{i}=$ Number of rooms in the home

$\mathrm{DSH}_{i}=$ Size of the dwelling of the household

$\mathrm{HRSE}_{i}=$ Hours of electricity supply 
$\mathrm{PFW}_{i}=$ Unit price of firewood per bundle

$\mathrm{NCF}_{i}=$ Similarity with the neighbor's main cooking fuel source

$\mathrm{HAPP}_{i}=$ Home appliances

$\mathrm{HOWN}_{i}=$ Home ownership

\section{The OLS Model}

Another objective of this study is to assess the determinants of household for biomass energy in Bauchi State.

Following Danlami (2014) and Lee (2013), the implicit form of the relationship between households' consumption of a particular energy and its determinants can be expressed as:

$$
Y_{i}=\beta_{0}+\sum_{i=0}^{k} \beta_{i} X_{i}
$$

where $Y_{i}$ is household i's consumption of biomass energy.

The estimated empirical OLS model for households' biomass energy consumption is expressed as:

$$
\begin{aligned}
\ln \mathrm{FWD}_{i}= & \alpha_{0}+\beta_{1} \mathrm{GEN}_{i}+\beta_{2} \mathrm{AGE}_{i}+\beta_{3} \mathrm{MST}_{i}+\beta_{4} \mathrm{EDU}_{i}+\beta_{5} \mathrm{HHS}_{i} \\
& +\beta_{6} \mathrm{INC}_{i}+\beta_{7} \mathrm{PFW}_{i}+\beta_{8} \mathrm{PKR}_{i}+\beta_{9} \ln \mathrm{HAPP}_{i}+\varepsilon_{i}
\end{aligned}
$$

where

$\mathrm{FWD}_{i}=$ Quantity of firewood bundle consume monthly.

$\mathrm{GEN}_{i}=$ Gender of the head of household

$\mathrm{AGE}_{i}=$ Age of the household head

$\mathrm{MST}_{i}=$ Marital status of the head of household

$\mathrm{EDU}_{i}=$ Level of education of the head of household

$\mathrm{HHS}_{i}=$ Size of the household

$\mathrm{Inc}_{i}=$ Monthly income of the head of household

$\mathrm{PFW}_{i}=$ Unit price of firewood per bundle

$\mathrm{PKR}_{i}=$ Price of kerosene per liter

$\mathrm{HAPP}_{i}=$ Number of home appliances own by household

\section{Analysis}

This study mainly analyzes two issues: household energy switching and the extent of household traditional biomass energy use. Table 1 indicates the estimated ordered logit model analyzing the determinants of household energy switching. Furthermore, Table 2 exhibits the estimated OLS model for the determinants of household 
Table 1 Estimated coefficients of energy switching (ordered logit model)

\begin{tabular}{|c|c|}
\hline Variables & Coefficients \\
\hline \multirow[t]{2}{*}{ Gender } & 0.7079 \\
\hline & $(0.5350)$ \\
\hline \multirow[t]{2}{*}{ Age } & $0.0233^{*}$ \\
\hline & $(0.0126)$ \\
\hline \multirow[t]{2}{*}{ Education } & $0.0869 * *$ \\
\hline & $(0.0416)$ \\
\hline \multirow[t]{2}{*}{ Household size } & $-0.1148^{* * *}$ \\
\hline & $(0.0376)$ \\
\hline \multirow[t]{2}{*}{ Lnincome } & $0.0106^{* * *}$ \\
\hline & $(0.0040)$ \\
\hline \multirow[t]{2}{*}{ Location } & $0.6118^{*}$ \\
\hline & $(0.3479)$ \\
\hline \multirow[t]{2}{*}{ Number of rooms } & -0.0512 \\
\hline & $(0.0388)$ \\
\hline \multirow[t]{2}{*}{ Dwshare } & -0.0075 \\
\hline & $(0.2634)$ \\
\hline Hours of electricity supply & $\begin{array}{l}0.0149 * * * \\
(0.0041)\end{array}$ \\
\hline \multirow[t]{2}{*}{ Firewood price } & 0.0024 \\
\hline & $(0.0038)$ \\
\hline \multirow[t]{2}{*}{ Ncfuel } & $-1.2996 * * *$ \\
\hline & $(0.2905)$ \\
\hline Home appliances & $\begin{array}{l}-0.0023 \\
(0.0103)\end{array}$ \\
\hline \multirow[t]{2}{*}{ Home ownership } & $\begin{array}{l}0.6069 * * \\
(0.2879)\end{array}$ \\
\hline & $(1.124)$ \\
\hline $\begin{array}{l}\text { Observations } \\
\text { Pseudo } \mathrm{R}^{2}\end{array}$ & $\begin{array}{l}444 \\
0.21\end{array}$ \\
\hline
\end{tabular}

$\chi^{2}(26)=72.56$

Prob $>\chi^{2}=0.0000$

Note: Robust standard errors in parentheses $* * * \mathrm{p}<0.01,{ }^{* *} \mathrm{p}<0.05,{ }^{*} \mathrm{p}<0.1$

traditional biomass consumption. The analysis and discussions of the estimated models are carried out in the following sections:

\section{Determinants of Household Energy Switching}

The first objective of this study is to assess the factors that determine the household movement along the energy ladder from traditional biomass energy to the available cleanest energy (electricity) in Bauchi State. To achieve this objective, ordered logit model was estimated and the result of the estimation is indicated in Table 1. 
Table 2 Determinants of household traditional biomass energy use

\begin{tabular}{l|l|l}
\hline Variables & Coefficients & Standard error \\
\hline Gender & 0.1190 & $(0.0834)$ \\
\hline Age & 0.0012 & $(0.0022)$ \\
\hline Marital status & $-0.1414^{* *}$ & $(0.0598)$ \\
\hline Education & $-0.0078^{*}$ & $(0.0046)$ \\
\hline Household size & $0.0168^{* * *}$ & $(0.0041)$ \\
\hline lnIncome & 0.0382 & $(0.0420)$ \\
\hline Price of firewood & $-0.0030^{* *}$ & $(0.0013)$ \\
\hline Price of Kerosene & $-0.0034^{* * *}$ & $(0.0010)$ \\
\hline lnhappls & -0.262 & $(0.0496)$ \\
\hline Constant & $3.9106^{* * *}$ & $(0.241)$ \\
\hline Observations & 270 & \\
\hline $\mathrm{R}^{2}$ & 0.13 & \\
\hline
\end{tabular}

Ramsey RESET Test (Specification test)

$\mathrm{F}(3,244)=5.63$

Prob $>\mathrm{F}=0.000$

Note: Robust standard errors in parentheses*** $\mathrm{p}<0.01, * * \mathrm{p}<0.05, * \mathrm{p}<0.1$

Based on the probability value of the Chi sq $\left(\mathrm{X}^{2}\right)$, in Table 1 , the estimated ordered logit model is jointly significant at $1 \%$, thereby implying the validity of the estimated ordered model. The result indicates that the coefficient of variable Age is statistically significant at $10 \%$ level. The result indicates that there is a positive relationship between the age of the household head and the household energy switching. A 1 year increase in the age of the household will lead to a $0.023 \mathrm{log}$ odd of household being in higher level of cleaner energy. This is in line with a priori expectation and conforms to the findings of Danlami (2017c). In the same vein, the coefficient of education was found to have a positive relationship with the household energy switching. The coefficient of the variable was found to be statistically significant at 5\% level. The estimated result shows that an increase in the level of education of the household head increases the log odd of household switching to cleaner energy by about 0.087 units. This is in line with a priori expectation because when the household head is more educated, he will have more awareness about the negative effects of using traditional biomass energy. This result supports the findings from Danlami et al. (2018b).

Contrarily, the coefficient of household size was found to have a negative relationship with the household energy switching. This coefficient was found to be statistically significant at $1 \%$ level. Based on the estimated result, a one unit increase in the number of household size decreases the log odd of switching to cleaner energy by about 0.115 units. This is in line with the findings of Danlami et al. (2019c). The coefficient of household income was found to be statistically significant at $1 \%$ level. The estimated result indicates that a $1 \%$ rise in the household income leads to increase in the log odd of household switching to the cleaner energy by about 0.011 units. This is in line with a priori expectation because as the household income increases, the affordability of the household to substitute traditional biomass energy 
with a cleaner energy increases. This supports the findings of Danlami (2017a). Similarly, the coefficient of household location was found to have a positive relationship with the household energy switching and it was found to be statistically significant at $10 \%$ level. Based on the result of the estimated ordered logit model, households that reside in urban areas of Bauchi State have higher log odd of switching to cleaner energy by about 0.612 units compared to their rural counter parts. This is in line with a priori expectations that the households living in urban areas adopt cleaner energy than the households living in the rural areas mainly due to economic, social, and educational factors. The exact fact is that cleaner sources of energy are more available in urban than in rural areas, which is in line with the findings of Danlami et al. (2018c).

The coefficient of hours of electricity supply was found to be statistically significant at $1 \%$ level and it was found to have a positive relationship with household energy switching. Based on the estimated model, $1 \mathrm{~h}$ increase in electricity supply increases the households' log odd of switching to cleaner energy by about 0.015 units. This conforms to a priori expectation that the tendency of households to move up the cleaner energy ladder increases when the electricity supply becomes more available and reliable. This supports the findings of Danlami et al. (2018b). Finally, the coefficient of home ownership was found to be statistically significant at 5\% level. Based on the estimated ordered logit model, there is a positive relationship between the coefficient of home ownership and switching to cleaner energy in Bauchi State. The households that live in their self-owned home have higher log odd of switching to cleaner energy by about 0.607 units than otherwise. This is in line with the findings of previous studies (Danlami et al. 2018b)

\section{Determinants of Household Traditional Energy Use}

Another objective of this study is to assess the factors that influence the quantity of traditional biomass energy use in Bauchi State, Nigeria. The result of the estimated model is in Table 2.

Based on Table 2, the estimated result shows that overall, the model is statistically significant at $1 \%$ level with an estimated F-value $=5.63$ and the corresponding probability value $\operatorname{Prob}(\mathrm{F})=0.000$. The result in Table 2 has shown that the estimated coefficient of marital status is statistically significant at 5\% level. On average, the households that are headed by a married person consume less traditional biomass energy by about $14 \%$ lower compared to the households that are headed by a nonmarried person. This does not conform to a priori expectation because the expectation is that when the head of a household is married, it means more number of household members which necessitates the use of more traditional biomass fuel such as firewood. However, this may be because the married household head in some cases signifies that he is at least more economically stronger to buy cleaner fuel than firewood. Based on the culture of the people in the study area, a person usually married when economically can afford the marriage responsibilities of which the 
purchase of cooking fuel is among. This finding supports the findings of other previous studies (Danlami 2019).

Moreover, the coefficient of level of education of the household was also found to be negative and statistically significant at $10 \%$ level. Based on the estimated OLS model, an additional year in the level of education reduces the household's use of traditional biomass energy by about $0.78 \%$. This conforms to a priori expectation that as more educated is the household head, the more he has health consciousness and also the more he knows the risk of using traditional biomass energy thereby minimizing the use of such energy. This is in line with the findings of Danlami (2017a) and Lee (2013). On the other hand, the coefficient of household size was found to be statistically significant at $1 \%$ and positively related to household use of traditional biomass energy. Based on the result shown in Table 2, increase in the number of household by one individual increases the household's use of traditional biomass energy by about $1.68 \%$. This conforms to a priori expectation and is in line with the findings of previous studies (Danlami 2017a).

The result also indicates that there is a negative significant relationship between traditional biomass energy use and its price. A one Naira increase in the price of firewood decreases the rate of household traditional biomass energy use by about $0.3 \%$ all things being equal. This is tally with a priori expectation because as the price of the traditional biomass energy increases, the household will switch to the use of available cheaper and cleaner energy. Similarly, when the price of a commodity rises, the purchasing power of buyers decreases, leaving the consumer with the ability to buy less of that commodity. This finding is in line with traditional law od demand which says that the higher the price, the lower the quantity demanded and also supports the findings of. Lastly, the result shows that price of kerosene has a negative impact on traditional biomass energy.

\section{Conclusions}

This study analyzes household energy switching along the energy ladder using ordered logit model. Also, the study uses OLS regression model to analyze the determinants of household traditional biomass energy use. The age of the household head and his level of education, income, living in urban areas, home ownership, and hours of electricity supply have positive significant impact on household energy switching from traditional biomass energy use to the cleaner energy. On the other hand, household size was found to have a negative relationship with household energy switching. Furthermore, the estimated OLS model indicates that household size has a positive and significant impact on traditional biomass energy use, the higher the household size, the high the quantity of traditional biomass energy consumption all things being equal. Marital status, household head level of education, and the price of the traditional biomass energy have negative significant impact on household use of traditional biomass energy. 


\section{Policy Recommendations}

Having conducted empirical investigation of household energy switching and traditional energy consumption in Bauchi State, Nigeria, the following recommendations were offered based on the study findings, in order to encourage households to switch to cleaner energy in the study area. Since increase in income was found to have significant impact in encouraging households' energy switching up to cleaner energy, policies and programs aimed at raising income earnings of individuals should be embarked upon to discourage the adoption and use of traditional biomass energy. Income can be increased via employment generation, wealth creation, increase in government expenditure, empowering small and medium scale industries, and skills acquisition and development programs.

The study finds that households that live in urban areas have higher probability and odd of switching to cleaner energy. In line with this finding, government should try to make cleaner energy available and affordable to rural dwellers as is in the urban areas. All the facilities that will ensure the availability of cheap cleaner energy in rural areas of the State should be established in order to encourage households to switch to cleaner energy in rural areas of the State.

The findings revealed that the level of formal education attainment by the household head has significant influence on switching to cleaner energy, the higher the level of education of the household head, the higher the odd of switching to the cleaner energy. Therefore, government should embarked upon policies to encourage higher education attainment of people leaving in the study area, especially rural areas whereby there are a large number of illiterate people. High rate of school enrolment can be increased via policies like free universal basic education programs, higher education enrolment at a subsidized rate, construction of more schools near to the people especially in rural areas, provision of more scholarships at higher levels, employing adequate number of teachers to meet the growing number of pupils, and increase in expenditure on educational facilities. The curriculum of the educational system should emphasize on the danger of high rate of environmental pollution and contamination especially in rural areas whereby the rate of awareness is very low.

Lastly, the study has found that adequate supply of electricity has significant impact on household switching to cleaner energy use. Therefore, provision of cheap and adequate electricity supply to households will encourage many households to use electricity as their main source of cooking and lighting, thereby reducing the rate of traditional biomass energy use.

\section{References}

Abdurrazak NTA, Medayese SO, Martins VI, Idowu OO, Adeleye BM, Bello LO (2012) An appraisal of household domestic energy consumption in Minna, Nigeria. J Environ Sci Toxicol Food Technol 2:16-24

Couture S, Garcia S, Reynaud A (2012) Household energy choices and fuelwood consumption: an econometric approach using French data. Energy Econ 34:1972-1981 
Danlami AH (2014) Examination of determinants of demand for Fertiliser in Tofa local government area, Kano State. Niger J Manag Technol Dev 5(2):1-14

Danlami AH (2017a) An analysis of household energy choice and consumption in Bauchi State, Nigeria [thesis]. School of Economics Finance and Banking: Universiti Utara Malaysia

Danlami AH (2017b) Determinants of household electricity consumption in Bauchi State, Nigeria. Hyper Econ J 5(1):16-28

Danlami AH (2017c) An intensity of household kerosene use in Bauchi State, Nigeria: a tobit analysi. Niger J Manag Technol Dev 8(2):1-13

Danlami AH (2019) Assessment of factors influencing firewood consumption in Bauchi State, Nigeria. J Sustain Sci Manag 14(1):99-109

Danlami AH, Islam R (2020) Explorative analysis of household energy consumption in Bauchi State, Nigeria. In: Editor A (ed) Energy efficiency and sustainable lighting - a bet for the future. IntechOpen, London

Danlami AH, Islam R, Applanaidu SD (2015) An analysis of the determinants of household energy choice: a search for conceptual framework. Int J Energy Econ Policy 5(1):197-205

Danlami AH, Islam R, Applanaidu SD, Tsauni AM (2016) An empirical analysis of fertiliser use intensity in rural Sub-Saharan Africa: evidence from Tofa local government area, Kano State, Nigeria. Int J Soc Econ 43(12):1400-1419

Danlami AH, Applanaidu SD, Islam R (2017) From biomass cooking fuel source to modern alternative for Bauchi State households: a preliminary analysis. Biofuels 8(3):323-331

Danlami AH, Applanaidu SD, Islam R (2018a) Movement towards a low carbon emitted environment: a test of some factors in Malaysia. Environ Dev Sustain 20(3):1085-1102

Danlami AH, Applanaidu SD, Islam R (2018b) An analysis of household cooking fuel choice: a case of Bauchi State, Nigeria. Int J Energy Sector Manag 12(2):265-283

Danlami AH, Applanaidu SD, Islam R (2018c) Axiom of the relative income hypothesis and household energy choice and consumption in developing areas: empirical evidence using Verme model. Kasetsart J Soc Sci 39:422-431

Danlami AH, Aliyu S, Danmaraya IA (2019a) Energy production, carbon emissions and economic growth in lower-middle income countries. Int J Soc Econ 46(1):97-115

Danlami AH, Applanaidu SD, Islam R (2019b) A micro level analysis of the adoption and efficiency of modern farm inputs use in rural areas of Kano State, Nigeria. Agric Res 8(3):392-402

Danlami AH, Applanaidu SD, Islam R (2019c) Movement towards the adoption of non-traditional household lighting fuel energy in developing areas. Biofuels 10(5):623-633

Desalu O, Ojo O, Aritibi E, Kolawale F, Idowu A (2012) A community survey of the pattern and determinants of household sources of energy for cooking in rural and urban South Western, Nigeria. Pan Afr Med Res J 2:1-12

Dillman DA (2011) Mail and internet surveys: the tailored design method 2007 update with new internet, visual, and mixed-mode guide. Hoboken, Wiley

Eakins J (2013) An analysis of the determinants of household energy expenditures: empirical evidence from the Irish household budget survey. $\mathrm{PhD}$ thesis, University of Surrey

Ganchimeg G, Havrland B (2011) Economic analysis of household energy consumption: the case of herders in Mongolia. Agric Trop Subtrop 44:197-203

Heltberg R (2005) Factors determining household fuel choice in Guatemala. Environ Dev Econ 10: 337-361

International Energy Agency (IEA) (2011) Energy balances of non-OECD countries. IEA, Paris

Jingchao Z, Kotani K (2011) The determinants of household energy demand in rural Beijing: can environmentally friendly technologies be effective? Energy Econ 34:381-388

Jumbe BLC, Angelsen A (2010) Modeling choice of fuelwood source among rural households in Malawi: a multinomial probit analysis. Energy Econ 33:732-738

Kofarmata YI (2016) An economic analysis of participation in credit market and credit rationing among farmers in Kano State, Nigeria [thesis]. School of Economics Finance and Banking, Universiti Utara Malaysia

Laureti T, Secondi L (2012) Determinants of households' space heating type and expenditures in Italy. Int J Environ Res 6(4):1025-1038 
Lee LY (2013) Household energy mix in Uganda. Energy Econ 39:252-261

Mensah T, Adu G (2013) An empirical analysis of household energy choice in Ghana. Uppsala working paper series no 6

Naibbi AI, Healey RG (2013) Northern Nigeria's dependence on fuelwood: insights from nationwide cooking fuel distribution data. Int J Humanit Soc Sci 3:160-173

NBS (2012) Annual abstract: federal republic of Nigeria. Retrieved February, 2016 from: http:// www.nigerianstat.gov.ng

Nlom JH, Karimov AA (2014) Modeling fuel choice among households in Northern Cameroon. WIDER working paper series, 2014/038.45

Nnaji C, Ukwueze E, Chukwu J (2012) Determinants of household energy choices for cooking in rural areas: evidence from Enugu State, Nigeria. Cont J Soc Sci 5(2):1-11

Ogwumike FO, Ozughalu UM, Abiona GA (2014) Household energy use and determinants: evidence from Nigeria. Int J Energy Econ Policy 4(2):248-262

Onoja AO (2012) Econometric analysis of factors influencing fuel wood demand in rural and Periurban farm households of Kogi State. J Sustain Dev 8(1):115-127

Osiolo HH (2010) Enhancing household fuel choice and substitution in Kenya. Kenya Institute for Public Policy Research, Nairobi

Oyekale A, Dare A, Olugbire O (2012) Assessment of rural households' cooking energy choice during kerosene subsidy in Nigeria: a case study of Oluyole local government area of Oyo State, Nigeria. Afr J Agric Res 7:5405-5411

Özcan KM, Gülay E, Üçdoğruk S (2013) Economic and demographic determinants of household energy use in Turkey. Energy Policy 60:550-557

Risseeuw N (2012) Household energy in Mozambique: a study on the socioeconomic and cultural determinants of stove and fuel transitions. Unpublished Master's thesis, Vrieje University, Amsterdam

Song N, Arguilar FX, Shifley SR, Goerndt ME (2012) Factors affecting wood energy consumption by U.S. households. Energy Econ 34:389-397

Suliman MK (2010) Factors affecting the choice of households' primary cooking fuel in Sudan. Research report presented to the Economic Research Forum, Cairo

Tchereni BH (2013) A microeconomic analysis of energy choice behaviour in South Lunzu Township, Malawi. Mediterr J Soc Sci 4(6):569-578

UNDP (2013) Human development report: Nigeria. Retrieved 22 November, 2014 from http:// resourcedat.com/wp-content/uploads/2013/05/Nigeria-HDI-value

Yamamoto S, Sie A, Sauerborn R (2009) Cooking fuels and the push for cleaner alternatives: a case study from Burkina Faso. Glob Health Action 2:156-164

Open Access This chapter is licensed under the terms of the Creative Commons Attribution 4.0 International License (http://creativecommons.org/licenses/by/4.0/), which permits use, sharing, adaptation, distribution and reproduction in any medium or format, as long as you give appropriate credit to the original author(s) and the source, provide a link to the Creative Commons license and indicate if changes were made.

The images or other third party material in this chapter are included in the chapter's Creative Commons license, unless indicated otherwise in a credit line to the material. If material is not included in the chapter's Creative Commons license and your intended use is not permitted by statutory regulation or exceeds the permitted use, you will need to obtain permission directly from the copyright holder. 